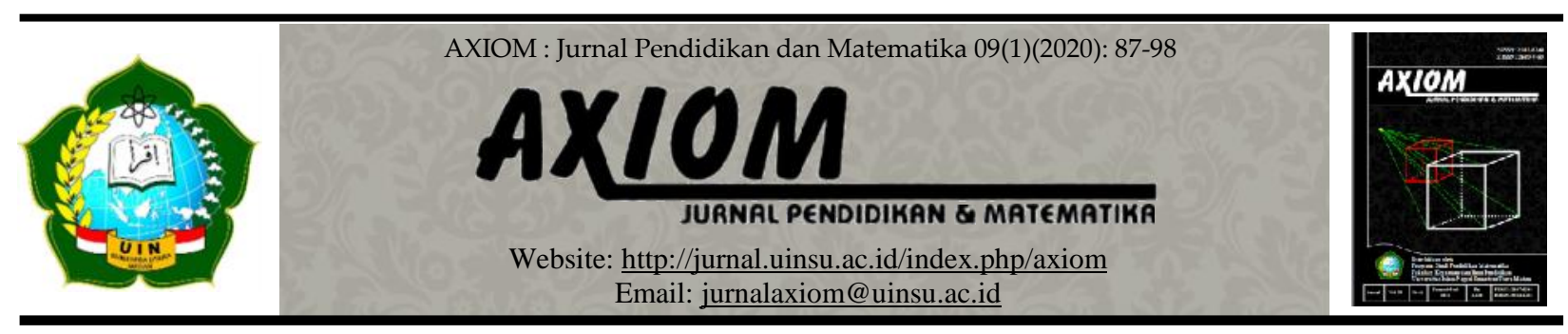

\title{
PENINGKATAN KEPERCAYAAN DIRI SISWA SMP DENGAN PEMBELAJARAN KOOPERATIF TIPE THINK PAIR SQUARE
}

\author{
Oleh:
}

\author{
Fitria Mardika ${ }^{1}$, Rusi Ulfa Hasanah ${ }^{2}$ \\ ${ }^{1}$ Tadris Matematika, Fakultas Tarbiyah dan Keguruan, Universitas Islam Negeri Imam Bonjol \\ Padang \\ ${ }^{2}$ Pendidikan Matematika, Fakultas Ilmu Tarbiyah dan Keguruan, Universitas Islam Negeri \\ Sumatera Utara \\ E-mail: ${ }^{1}$ fitriamardika@uinib.ac.id, ${ }^{2}$ rusiulfahasanah@uinsu.ac.id
}

doi : 10.3082/axiom.v\%vi\%i.7267

\begin{abstract}
Abstrak:
Kepercayaan diri siswa menjadi hal yang penting dalam mempersiapkan siswa menghadapi kehidupan yang semakin menantang. Salah satu metode yang dapat digunakan untuk meningkatkan kepercayaan diri siswa adalah pembelajaran kooperatif tipe Think Pair Square (TPS). Pembelajaran kooperatif tipe TPS adalah model pembelajaran kelompok heterogen yang memberikan kesempatan kepada siswa untuk berpikir mandiri kemudian mendiskusikan hasil pemikirannya dengan pasangan berdua dan berempat. Dalam meningkatkan kepercayaan diri siswa ini dilakukan penelitian tindakan kelas menggunakan pembelajaran kooperatif tipe TPS untuk siswa SMP. Selama Oktober hingga Desember 2018 penelitian dilakukan sebanyak dua siklus dan diterapkan kepada 32 siswa SMP di Pekanbaru. Data penelitian diperoleh dari instrumen non tes yaitu angket kepercayaan diri, lembar pengamatan guru dan siswa, catatan peneliti, dan lembar refleksi. Kondisi awal menunjukkan rata-rata kepercayaan diri siswa berada pada kriteria sedang. Setelah siklus 1 diperoleh rata-rata kepercayaan diri siswa meningkat menjadi kriteria tinggi, namun masih terdapat beberapa catatan yang ditulis dalam lembar refleksi. Setelah adanya perbaikan, rata-rata kepercayaan diri siswa berada pada kriteria tinggi dengan nilai rata-rata yang meningkat dibanding siklus 1 dikarenakan adanya upaya perbaikan yang disesuaikan dengan rencana. Hal ini memperlihatkan bahwa target peningkatan kepercayaan diri siswa SMP tercapai melalui pembelajaran kooperatif tipe TPS, dengan kondisi siswa berada pada kelas VIII dengan kelas yang heterogen dan kemampuan kognitif siswa rata-rata berada pada kategori sedang.
\end{abstract}

Kata Kunci:

Kepercayaan Diri, Pembelajaran Kooperatif, Think Pair Square.

\section{Abstract:}

Student confidence is important in preparing students for increasingly challenging lives. One method that can be used to improve student confidence is Think Pair Square (TPS) cooperative learning. TPS type cooperative learning is a heterogeneous group learning model that provides opportunities for students to think independently then discuss the results of their thinking with partners of two and four. In increasing students' confidence, a classroom action research study 
using TPS cooperative learning for junior high school students was conducted. During October to December 2018 the study was conducted in two cycles and applied to 32 junior high school students in Pekanbaru. The research data were obtained from non-test instruments namely selfconfidence questionnaire, teacher and student observation sheets, researcher notes, and reflection sheets. The initial conditions indicate the average level of student confidence is at the medium criteria. After cycle 1, the average student's self-confidence is increased to a high criterion, but there are still some notes written in the reflection sheet. After the improvement, the average student confidence is at a high criterion with an average value that increases compared to cycle 1 due to the improvement effort that is adjusted to the plan. This shows that the target of increasing the confidence of junior high school students is achieved through cooperative learning type TPS, with the condition of students in class VIII with heterogeneous classes and cognitive abilities of students in the average category is in the medium category.

Keywords:

Self Confidence, Cooperative Learning, Think Pair Square .

\section{A. Pendahuluan}

Banyak faktor yang mempengaruhi keberhasilan belajar, salah satunya faktor nonkognitif yaitu kepercayaan diri. Kepercayaan diri merupakan salah satu aspek kepribadian yang sangat penting dalam kehidupan manusia. Hannula, Maijala, dan Pehkonen (2004: 17) menyatakan bahwa pembelajaran matematika dipengaruhi oleh keyakinan kemampuan diri yang dimiliki oleh siswa terutama rasa percaya diri. Dengan kepercayaan diri yang bagus, seseorang akan yakin atas kemampuan diri sendiri serta memiliki pengharapan yang realistis. Kepercayaan diri sangat dibutuhkan dalam mempelajari matematika karena bagaimanapun perkembangan matematika dan teknologi merupakan fondasi kehidupan setiap saat sehingga matematika tetap harus dipelajari (NCTM, 2000: 4). Siswa yang memiliki kepercayaan diri yang baik akan berani mencoba presentasi di depan kelas, berani berpendapat, bertanya ataupun menjawab pertanyaan sehingga mampu menciptakan proses pembelajaran yang aktif seperti yang tercantum dalam standar proses pendidikan.

Kenyataannya, kepercayaan diri siswa kelas VIII di salah satu SMP Kota Pekanbaru belum sesuai dengan harapan. Hal ini dapat dilihat dari hasil angket yang telah diberikan oleh peneliti pada Tabel 1 .

Tabel 1. Hasil Angket Kepercayaan Diri Siswa Kelas VIII SMP Kota Pekanbaru Kriteria Kepercayaan Diri

Sangat Tinggi

Tinggi

Sedang

Rendah

Sangat Rendah
Persentase Siswa

$0 \%$

$6.67 \%$

$80 \%$

$13.33 \%$

$0 \%$

Salah satu cara untuk meningkatkan kepercayaan diri siswa adalah dengan kerja kelompok. Dalam kerja kelompok dimana melakukan kerjasama dalam belajar, setiap anggota kelompok kadang-kadang mempunyai perasaan untuk mempertahankan nama baik kelompok sehingga menjadi pendorong yang kuat dalam belajar (Hamalik, 2007). Mengingat kemampuan siswa bersifat heterogen maka tidak tertutup kemungkinan ada siswa yang hanya bergantung pada siswa lainnya sehingga diperlukan suatu model pembelajaran dimana setiap siswa diberikan kesempatan untuk berusaha memahami materi secara mandiri terlebih dahulu. Kemudian, juga diperlukan pendekatan agar siswa juga dapat menyelesaikan permasalahan yang tidak bisa diselesaikan secara mandiri. Salah satu model pembelajaran yang demikian adalah pembelajaran kooperatif TPS. Lie (2008) mengatakan TPS merupakan salah satu teknik pembelajaran yang memberi kesempatan kepada siswa untuk bekerja sendiri serta bekerja sama dengan orang lain. 
Terdapat penelitian yang menyatakan TPS dapat meningkatkan aktivitas dan kepercayaan diri siswa, yaitu penelitian yang dilakukan oleh Aisah, Ashari, \& Akhdinirwanto (2013) serta penelitian Susanti (2010). Dengan diterapkannya pembelajaran kooperatif TPS dalam kegiatan pembelajaran maka diharapkan kepercayaan diri siswa akan meningkat. Berdasarkan pertimbangan di atas, maka dilakukan penelitian sebagai upaya untuk meningkatkan kepercayaan diri siswa kelas VIII melalui pembelajaran kooperatif TPS tahun pelajaran 2018/2019 pada materi pokok teorema pythagoras dan statistika.

\section{B. Kajian Teoritis}

\section{Pembelajaran Matematika}

Belajar dimaknai sebagai proses membangun pengetahuan (Young, 2015: 17). Lebih lanjut pembelajaran adalah proses aktif dimana siswa membangun hubungan antara pengetahuan baru yang disajikan dengan pengetahuan yang sudah dimilikinya (Kemp, Morrison, \& Ross, 1994; Haylock \& Thangata, 2007). Proses belajar yang dilakukan di kelas dinamakan pembelajaran. Hal yang terpenting dalam proses pembelajaran adalah menciptakan suatu kondisi belajar yang kondusif untuk mencapai hasil tertentu sebagai suatu tujuan. Brockbank \& McGill (2007: 17) yang menyatakan bahwa pembelajaran dapat dipandang sebagai kata benda maupun kata kerja, apabila dipandang sebagai kata benda maka pembelajaran adalah hasil berupa pengetahuan, keterampilan, sikap, atau nilai yang diperoleh saat belajar atau melalui pengalaman, sedangkan apanila dipandang sebagai kata kerja maka pembelajaran adalah proses dalam memperoleh pengetahuan, keterampilan, sikap, dan nilai. Nitko \& Brookhart (2011: 18) bahwa pembelajaran adalah proses yang digunakan untuk mengkondisikan siswa dalam mencapai tujuan pembelajaran. Dapat disimpulkan bahwa pembelajaran adalah aktivitas pengolahan informasi yang dilakukan oleh guru dan siswa dengan berbagai komponen serta faktor pendukungnya untuk mencapai tujuan tertentu.

Matematika sebagai salah satu bidang studi penentu kelulusan siswa menjadi perhatian utama bagi para pemerhati pendidikan. Terkhusus bahwa matematika digunakan sebagai terapan untuk beberapa ilmu dan berbagai bidang. Hal ini sesuai dengan yang dinyatakan dalam NCTM (2000: 66) bahwa "Mathematics is used in science, the social sciences, medicine, and commerces". Hakikat matematika sendiri dinyatakan dalam Mathematical Sciences Education Board (Van de Walle, 2007: 12) bahwa sebagai sesuatu yang sifatnya praktis, matematika merupakan ilmu tentang pola dan ukuran. Matematika tidak membahas tentang molekul atau sel, tetapi membahas tentang bilangan, kemungkinan, bentuk, algoritma, dan perubahan. Sebagai ilmu dengan objek yang abstrak, matematika bergantung pada logika, bukan pada pengamatan sebagai standar kebenarannya, meskipun menggunakan pengamatan, stimulasi, dan bahkan percobaan sebagai alat untuk menemukan kebenaran. Dapat disimpulkan bahwa matematika adalah ilmu tentang suatu ide abstrak yang memiliki pola keteraturan yang logis serta aktivitasnya dalam menyatakan ide-ide tersebut.

Khusus untuk mata pelajaran matematika, pembelajaran memiliki peran yang sangat penting dalam perkembangan pola pikir matematis siswa ke depannya. Melalui pembelajaran matematika, siswa memiliki kemampuan untuk meningkatkan kemampuan berpikir logis, analitis, sistematis, kritis, dan kreatif, serta kemampuan bekerjasama. Kompetensi tersebut diperlukan agar siswa dapat memiliki kemampuan memperoleh, mengelola, dan memanfaatkan informasi untuk bertahan hidup pada keadaan yang selalu berubah, tidak pasti, dan kompetitif.

Dengan demikian pembelajaran matematika merupakan suatu proses yang mengandung interaksi antara guru dan siswa yang sengaja dirancang dengan tujuan untuk menciptakan suasana lingkungan yang memungkinkan bagi siswa untuk melaksanakan kegiatan belajar matematika sesuai dengan tujuan pembelajaran matematika. Selama proses pembelajaran matematika berlangsung, siswa harus aktif dalam menyelidiki dan menyelesaikan permasalahanpersalahan matematis sesuai dengan tujuan yang telah ditetapkan. 


\section{Kepercayaan Diri}

Kepercayaan diri merupakan salah satu indikator untuk mencapai suatu tujuan. Kepercayaan diri memberikan dorongan yang kuat pada seseorang untuk melakukan sesuatu yang sulit. Hal ini mengakibatkan kepercayaan diri menjadi faktor pendukung bagi kemajuan seseorang, terutama dalam hal belajar. Sesuai dengan yang diungkapkan oleh Hebaish (2012: 1) bahwa percaya diri menjadi salah satu variabel yang paling mempengaruhi belajar. Dengan kepercayaan diri yang bagus, seseorang akan yakin atas kemampuan mereka sendiri serta memiliki pengharapan yang realistis, bahkan ketika harapan mereka tidak terwujud mereka tetap berpikiran positif dan dapat menerimanya.

Schunk (2012: 498) menyatakan bahwa kepercayaan diri diartikan sebagai sebuah kepercayaan untuk bisa memberikan hasil, mencapai tujuan, atau melakukan tugas secara kompeten. Yoder \& Proctor (1988: 4-5) menyebutkan bahwa kepercayaan diri merupakan ungkapan aktif, efektif dari perasaan mengenai harga diri, konsep diri, dan pemahaman akan dirinya sendiri. Menurut Goel \& Aggarwal (2012: 89) kepercayaan diri adalah satu dari sifat kepribadian yang merupakan gabungan dari pikiran dan perasaan, kerja keras dan harapan, ketakutan dan rasa kagum, pandangannya terkait apa dia, selama ini apa dia, akan menjadi apa dia, dan sikapnya yang berkaitan dengan nilai yang diyakininya. Kemudian Syaifullah (2010: 10) menambahkan bahwa percaya diri merupakan sikap positif yang dimiliki seorang individu yang membiasakan dan memupukkan dirinya untuk mengembangkan penilaian positif baik terhadap diri sendiri maupun terhadap orang lain, lingkungan serta situasi yang dihadapinya untuk meraih apa yang diinginkan.

Yorder \& Proctor (1988: 4) menyatakan beberapa kemampuan yang memperlihatkan anak yang memiliki kepercayaan diri, yakni sebagai berikut: (a) Bersikap tegas, tanpa menjadi agresif, (b) Teguh pada keyakinan, bahkan ketika orang lain berdiri melawannya, (c) Mudah bergaul, (d) Tetap dengan suatu pekerjaan sampai selesai dan cukup menjamin untuk mengetahui bahwa yang terbaik dia lakukan adalah sudah cukup baik, (e) Menerima kekalahan dan penolakan dengan tenang dan bangkit kembali dengan cepat dan penuh semangat, (f) Bekerja dengan baik bersama orang lain sebagai anggota "tim", (g) Memegang peran kepemimpinan tanpa ragu-ragu di saat yang tepat, dan (h) Mengharapkan untuk menjadi seorang pemimpin, setidaknya pada beberapa kesempatan. Syaifullah (2010: 17) juga menyatakan beberapa ciri-ciri pribadi yang memiliki sikap percaya diri, yaitu: (a) Percaya dengan kemampuan diri sendiri, (b) Mengutamakan usaha sendiri, tidak tergantung pada orang lain, (c) Tidak mudah mengalami rasa putus asa, (d) Berani menyampaikan pendapat, (e) Mudah berkomunikasi dan membantu orang lain (e) Tanggung jawab dengan tugas-tugasnya, dan (f) Memiliki cita-cita untuk meraih prestasi.

Sementara Adywibowo (2010: 41) menyatakan indikator kepercayaan diri meliputi mandiri, mudah berkomunikasi dengan orang lain, berani menerima tugas/tantangan baru, dan dapat mengekspresikan emosi dengan wajar. Dari pendapat-pendapat di atas, disimpulkan bahwa kepercayaan diri adalah keyakinan yang dimiliki oleh seorang individu terhadap dirinya sendiri yang dapat dilihat dengan sikap yakin dan percaya dengan kemampuan yang dimiliki, memiliki sikap optimis, dan berani menerima tantangan yang diberikan.

\section{Pembelajaran Kooperatif}

Pembelajaran kooperatif merupakan pembelajaran yang menekankan strategi pembelajaran kelompok dimana siswa saling membantu satu sama lain. Slavin (2005: 4) menyatakan bahwa pembelajaran kooperatif merujuk pada berbagai macam metode pembelajaran yang diterapkan pada kelas yang terdiri atas kelompok-kelompok kecil dengan kemampuan yang heterogen. Diharapkan siswa dapat saling membantu, mendiskusikan dan berargumentasi untuk mengasah pengetahuan yang mereka kuasai saat itu dan menutup kesenjangan dalam pemahaman masing-masing. Hal ini dipertegas oleh Marsh (2004: 117) yang menyatakan bahwa pembelajaran kooperatif merupakan suatu teknik pemberian tugas kepada kelompok dan kelompok tersebut berusaha untuk menyelesaikannya dimana siswa dalam kelompok tersebut harus saling berinteraksi dan membantu untuk melengkapi tugas secara 
keseluruhan, diharapkan dengan kegiatan tersebut akan memperkaya pengetahuan masingmasing siswa. Menurut Eggen dan Kauchak (Trianto, 2011: 42) pembelajaran kooperatif merupakan sebuah kelompok strategi pengajaran yang melibatkan siswa bekerja secara berkolaborasi untuk mencapai tujuan bersama. Hal ini diperjelas oleh Sanjaya (2010: 242) yang menyatakan bahwa pembelajaran kooperatif merupakan model pembelajaran dengan menggunakan sistem pengelompokan/tim kecil, yaitu antara empat sampai enam orang yang mempunyai latar belakang kemampuan akademis, jenis kelamin, ras atau suku yang berbeda (heterogen).

Ibrahim, dkk (Trianto 2011: 48) mengatakan bahwa terdapat enam langkah utama atau tahapan di dalam pembelajaran kooperatif. Dimulai dengan penyampaian tujuan pembelajaran dan diakhiri dengan pemberian penghargaan. Berikut pada Tabel 2 ditampilkan langkah-langkah model pembelajaran kooperatif.

Tabel 2. Langkah-langkah pembelajaran kooperatif

\begin{tabular}{|c|c|}
\hline Fase & Tingkah Laku Guru \\
\hline Fase-1 & Guru menyampaikan semua tujuan pembelajaran yang \\
\hline $\begin{array}{l}\text { Menyampaikan tujuan dan } \\
\text { memotivasi siswa. }\end{array}$ & $\begin{array}{l}\text { ingin dicapai pada pelajaran tersebut dan memotivasi siswa } \\
\text { belajar. }\end{array}$ \\
\hline Fase-2 & Guru menyajikan informasi kepada siswa dengan jalan \\
\hline Menyajikan informasi & demonstrasi atau lewat bahan bacaan. \\
\hline Fase-3 & Guru menjelaskan kepada siswa bagaimana caranya \\
\hline $\begin{array}{l}\text { Mengorganisasikan siswa ke } \\
\text { dalam kelompok-kelompok } \\
\text { belajar. }\end{array}$ & $\begin{array}{l}\text { membentuk kelompok-kelompok belajar dan membantu } \\
\text { setiap kelompok agar melakukan transisi secara efisien. }\end{array}$ \\
\hline Fase-4 & Guru membimbing kelompok-kelompok belajar pada saat \\
\hline $\begin{array}{l}\text { Membimbing kelompok bekerja } \\
\text { dan belajar }\end{array}$ & mereka mengerjakan tugas mereka. \\
\hline Fase-5 & Guru mengevaluasi hasil belajar tentang materi yang telah \\
\hline Evaluasi. & $\begin{array}{l}\text { dipelajari atau masing-masing kelompok mempresentasikan } \\
\text { hasil kerjanya. }\end{array}$ \\
\hline Fase-6 & Guru mencari cara-cara untuk menghargai, baik upaya \\
\hline Memberikan penghargaan & maupun hasil belajar individu dan kelompok. \\
\hline
\end{tabular}

\section{Model Pembelajaran Kooperatif Tipe Think Pair Square}

Model pembelajaran kooperatif Think Pair Square merupakan hasil modifikasi dari model Think Pair Share yang dikembangkan oleh Spencer Kagan. Pendekatan ini memberi penekanan pada penggunaan struktur tertentu yang dirancang untuk mempengaruhi pola interaksi siswa. Struktur ini menghendaki siswa bekerja saling membantu dalam kelompok kecil dan lebih dicirikan oleh penghargaan kooperatif, daripada menghargaan individual. Struktur TPS dapat digunakan oleh guru untuk mengajarkan isi akademik atau untuk mengecek pemahaman siswa terhadap isi tertentu (Ibrahim, dkk., 2001).

Dalam pembelajaran kooperatif pendekatan struktural TPS guru membagi siswa dalam kelompok heterogen yang beranggotakan empat orang. Sebagai kegiatan awal adalah think atau tahap berpikir, setiap siswa diberi kesempatan untuk membaca, memahami, memikirkan kemungkinan jawaban dan mencatat hal-hal yang kurang dipahami yang berhubungan dengan tugas. Tujuannya adalah agar setiap siswa memberikan respon terhadap ide-ide yang terdapat dalam lembar kerja siswa dan menterjemahkannya ke dalam bahasa sendiri.

Tahap selanjutnya adalah pair atau tahap berpasangan. Pada tahap ini, siswa diminta untuk berpasangan dengan salah seorang teman dalam kelompoknya untuk mendiskusikan kemungkinan jawaban atau hal-hal yang telah diperoleh dalam tahap think. Dengan berpasangan, partisipasi aktif siswa dalam kelompok dapat lebih ditingkatkan. Setelah tahap pair atau 
berpasangan, kemudian tahap square, dimana pasangan bergabung dengan pasangan yang lain dalam kelompoknya untuk membentuk kelompok berempat. Kemudian kelompok ini mendiskusikan tugas-tugas yang belum diselesaikan atau hal-hal yang belum dipahami ketika diskusi, kemudian menetapkan hasil akhir jawaban kelompoknya.

Lie (2008) mengatakan dengan adanya tahap pair dan square, terjadi lebih banyak diskusi, sehingga dapat lebih meningkatkan dan mengoptimalkan partisipasi aktif siswa dalam kelompok. Selain itu siswa juga akan memiliki lebih banyak kesempatan untuk berdiskusi dalam kelompoknya, dan interaksi antara siswa juga lebih mudah. Menurut Lie (2008: 58) terdapat empat tahapan dalam teknik TPS yaitu sebagai berikut: (a) Guru membagi siswa dalam kelompok yang anggotanya empat orang dan memberikan tugas kepada semua kelompok, (b) Setiap siswa memikirkan dan mengerjakan tugas tersebut sendiri, (c) Siswa berpasangan dengan salah satu rekan dalam kelompok dan berdiskusi dengan pasangannya, dan (d) Kedua pasangan bertemu kembali dengan kelompok berempat. Setiap siswa mempunyai kesempatan untuk membagi hasil kerja kepada kelompok berempat.

\section{Metode Penelitian}

\section{Jenis Penelitian}

Bentuk penelitian yang dilakukan adalah Penelitian Tindakan Kelas (PTK) yang dilakukan secara kolaboratif, yaitu peneliti dan guru bekerja sama dalam proses pelaksanaan tindakan. Pelaksanaan tindakan dilakukan oleh peneliti sendiri dan guru matematika kelas VIIIC MTs Negeri Maguwoharjo. Penelitian ini terdiri dari 2 siklus, yaitu dengan melakukan tindakan yang mengacu pada pembelajaran kooperatif TPS.

Desain PTK yang digunakan adalah desain oleh Kemmis dan McTaggart yaitu terdiri dari empat langkah, yaitu perencanaan (planning), pelaksanaan (action), pengamatan (observing) dan refleksi (reflecting). Siklus penelitian tindakan kelas digambarkan sebagai berikut.

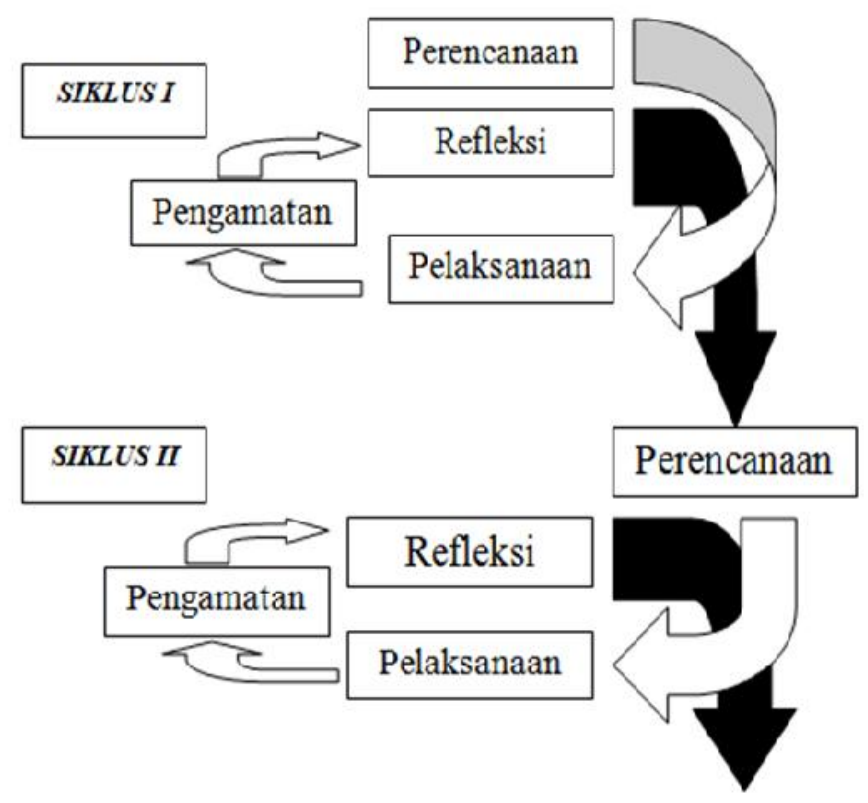

Gambar 1. Siklus Penelitian Tindakan Kelas

\section{Waktu dan Tempat Penelitian}

Penelitian ini dilaksanakan pada semester ganjil tahun pelajaran 2018/2019. Penelitian berlangsung selama dua bulan dimulai dari awal pelaksanaan pra-survey hingga pelaksanaan penelitian yang dilakukan pada tanggal 10 Oktober 2018 sampai dengan 17 November 2018.

\section{Target/Subjek Penelitian/Populasi dan Sampel}


Subjek penelitian adalah siswa kelas VIIIC MTs Negeri Maguwoharjo sebanyak 32 orang yang terdiri dari 20 orang laki-laki dan 12 orang perempuan dengan tingkat kemampuan yang heterogen.

\section{Prosedur}

Tindakan yang dilakukan dalam penelitian ini terdiri dari dua siklus. Tahap yang dilakukan pada siklus satu adalah sebagai berikut. (a) Perencanaan (planning). Peneliti terlebih dahulu melakukan observasi lokasi dan subjek penelitian serta konsultasi dengan pihak guru. Peneliti kemudian menyusun instrumen penelitian yang terdiri dari perangkat pembelajaran dan instrumen pengumpul data. Pada tahap ini ditetapkan kelas yang mengikuti pembelajaran dengan menggunakan model pembelajaran kooperatif TPS. Sebelumnya peneliti telah masuk ke kelas untuk menjelaskan tata cara pembelajaran yang akan dilakukan oleh siswa selama penelitian. Selain itu peneliti juga membagi siswa dalam kelompok-kelompok kooperatif dengan masingmasing kelompok terdiri dari 4 siswa yang heterogen dalam bidang akademiknya. Kelompok ini disusun berdasarkan nilai dasar siswa yang diambil dari nilai ulangan harian pada materi persamaan garis lurus. Peneliti juga menyusun tempat duduk siswa, yaitu siswa akan duduk seperti belajar klasikal namun dengan saling menjarakkan meja. Hal ini bertujuan agar pada tahap think, siswa mengerjakan LKS secara individu tanpa bekerjasama dengan teman disebelahnya. Selain itu susunan tempat duduk siswa juga bersebelahan dengan pasangan serta berdekatan dengan pasangan lain dalam kelompoknya agar pada tahap pair ataupun square siswa tidak kesulitan untuk bergabung dengan pasangan maupun kelompoknya. Peneliti juga menginstrusikan agar pada saat pembelajaran matematika, seluruh siswa harus duduk pada posisi yang telah disusun oleh peneliti. (b) Pelaksanaan tindakan (action). Pada tahap ini, peneliti menerapkan pembelajaran kooperatif TPS. Pelaksanaan berpedoman pada perangkat pembelajaran yang telah disusun. (c) Pengamatan (observing). Pada tahap ini, dilakukan pengamatan mengenai aktivitas guru dan siswa selama proses pembelajaran. Pengamatan berpedoman pada lembar observasi kegiatan guru dan siswa yang telah disusun. (d) Refleksi (reflecting). Pada tahap ini, peneliti dan pengamat mendiskusikan kekurangan dan kelemahan yang tampak pada tahap pengamatan selama satu siklus.

Untuk siklus kedua, tahapan yang dilakukan adalah sebagai berikut. (a) Perencanaan (Planning). Perencanaan yang dilakukan pada siklus 2 meliputi perbaikan rencana pelaksanaan pembelajaran dan lembar kerja siswa yang sudah disusun sebelumnya didasarkan pada hasil refleksi siklus 1. (b) Pelaksanaan tindakan (Action). Pada tahap ini, peneliti menerapkan Pembelajaran Kooperatif TPS. Pelaksanaan berpedoman pada perangkat pembelajaran yang telah disusun serta memperbaiki kekurangan hasil refleksi siklus 1. (c) Pengamatan (Observing). Pada tahap ini, dilakukan pengamatan mengenai aktivitas guru dan siswa selama proses pembelajaran. Pengamatan berpedoman lembar observasi kegiatan guru dan siswa yang telah diperbaiki. (d) Refleksi (Reflecting). Pada tahap ini, peneliti dan pengamat mendiskusikan kekurangan dan kelemahan yang tampak pada tahap pengamatan selama satu siklus.

\section{Data, Intrumen, dan Teknik Pengumpulan Data}

a. Observasi

Observasi dilakukan untuk mendapatkan data mengenai keterlaksanaan pembelajaran yang dilakukan selama penelitian dengan model pembelajaran kooperatif TPS. Instrumen yang digunakan pada observasi ini adalah lembar pengamatan keterlaksanaan proses pembelajaran yang terdiri dari kegiatan guru dan siswa. Pengamat akan memberikan checklist pada kegiatan yang telah dilakukan selama proses pembelajaran berlangsung. Lembar ini nantinya akan menjadi bahan refleksi serta bahan perbaikan untuk siklus berikutnya.

\section{b. Non Tes}

Teknik non tes dilakukan untuk mendapatkan data mengenai kepercayaan diri siswa. Instrumen yang digunakan adalah angket kepercayaan diri siswa. Angket diberikan sebelum 
penelitian, akhir siklus 1, dan akhir siklus 2. Angket terdiri dari 30 pertanyaan yang disusun berdasarkan indikator dari kepercayaan diri. Adapun indikator serta sebaran butir dari angket kepercayaan diri siswa ditunjukkan pada Tabel 3 berikut.

Tabel 3. Indikator dan Sebaran Butir Angket Kepercayaan Diri

\begin{tabular}{ccccc}
\hline \multirow{2}{*}{ No. } & \multirow{2}{*}{ Indikator } & \multicolumn{2}{c}{ Nomor Butir } & \multirow{2}{*}{$\begin{array}{c}\text { Jumlah } \\
\text { Butir }\end{array}$} \\
\cline { 3 - 4 } & & Positif & Negatif & 10 \\
1. & Yakin & $1,3,5,7,9$ & $2,4,6,8,10$ & 10 \\
2. & Optimis & $11,13,15,17,19$ & $12,14,16,18,20$ & 10 \\
3. & Berani & $21,23,25,27,29$ & $22,24,26,28,30$ & 30 \\
\hline
\end{tabular}

\section{Teknik Analisis Data}

\section{a. Data Keterlaksanaan Proses Pembelajaran}

Data diperoleh dari lembar observasi keterlaksanaan pembelajaran yang telah diisi oleh pengamat. Butir pengamatan yang bertanda check $(\sqrt{ })$ diberi skor 1 dan yang bertanda silang diberi skor 0. Masing-masing kegiatan guru dan siswa dihitung skor total kemudian dipersentasekan sehingga dapat diketahui seberapa besar peningkatan keterlaksanaan kegiatan pembelajaran dengan model pembelajaran kooperatif TPS tiap pertemuannya. Hasil analisis data observasi kemudian disajikan secara deskriptif.Untuk menghitung presentase keterlaksanaan pembelajaran yang diamati dengan menggunakan lembar observasi keterlaksanaan pembelajaran dapat dihitung dengan:

$$
\text { Persentase }(P)=\frac{\text { Jumlah tahapan pembelajaran yang terlaksana }}{\text { Jumlah keseluruhan tahapan pembelajaran }} \times 100 \%
$$

\section{b. Data Kepercayaan Diri}

Data diperoleh dari angket kepercayaan diri yang diisi oleh siswa. Tiap butir diberikan skor sesuai dengan skala. Skala yang digunakan adalah skala likert dengan ketentuan penskoran sebagai berikut.

Tabel 4. Skala Penilaian Angket Kepercayaan Diri

\begin{tabular}{cccccc}
\hline \multirow{2}{*}{ Pernyataan } & Selalu & Sering & $\begin{array}{c}\text { Kadang- } \\
\text { kadang }\end{array}$ & Jarang & $\begin{array}{c}\text { Tidak } \\
\text { Pernah }\end{array}$ \\
\cline { 2 - 6 } & 5 & 4 & 3 & 2 & 1 \\
Positif & 1 & 2 & 3 & 4 & 5 \\
Negatif & 1 & &
\end{tabular}

Data kepercayaan diri masing-masing siswa yang diperoleh digolongkan dalam kriteria berdasarkan Tabel 10. Penskoran untuk skala kepercayaan diri siswa pada penelitian ini memiliki rentang antara 30 sampai dengan 150, karena nilai terendah dalam penskoran angket adalah 30 dan nilai tertinggi adalah 150 . Untuk menentukan kriteria hasil pengukurannya digunakan klasifikasi berdasarkan rata-rata ideal $(\mathrm{Xi})$ dan standar Deviasi ideal $(\mathrm{Si})$. $\mathrm{Mi}=(30+150) / 2=90$ dan $\mathrm{Si}=(150-30) / 6=20$.

Tabel 5. Kategorisasi Kepercayaan Diri Siswa

\begin{tabular}{cccc}
\hline No & Interval & Skor $(\mathbf{X})$ & Kriteria \\
\hline 1 & $\mathrm{Xi}+1,8 \mathrm{Si}<\mathrm{X}$ & $126<\mathrm{X}$ & Sangat Tinggi \\
2 & $\mathrm{Xi}+0,6 \mathrm{Si}<\mathrm{X} \leq \mathrm{Xi}+1,8 \mathrm{Si}$ & $102<\mathrm{X} \leq 26$ & Tinggi \\
3 & $\mathrm{Xi}-0,6 \mathrm{Si}<\mathrm{X} \leq \mathrm{Xi}+0,6 \mathrm{Si}$ & $78<\mathrm{X} \leq 02$ & Sedang \\
4 & $\mathrm{Xi}-1,8 \mathrm{Si}<\mathrm{X} \leq \mathrm{Xi}-0,6 \mathrm{Si}$ & $54<\mathrm{X} \leq 78$ & Rendah \\
5 & $\mathrm{X} \leq \mathrm{Xi}-1,8 \mathrm{Si}$ & $\mathrm{X} \leq 54$ & Sangat Rendah \\
\hline
\end{tabular}




\section{Hasil Penelitian dan Pembahasan \\ 1. Hasil}

Pada siklus 1, kegiatan perencanaan telah dilakukan yaitu menentukan materi pembelajaran (teorema pythagoras) serta jadwal pertemuan di kelas, perangkat pembelajaran, kelompok siswa, memberikan angket kepercayaan diri, dan menyusun lembar observasi. Kegiatan pelaksanaan dilakukan dalam 3 pertemuan. Selama pertemuan tersebut dicatatlah kegiatan guru dan siswa yang berlangsung serta peneliti menuliskan catatan-catatan mengenai apa yang terjadi selama pembelajaran. Persentase keterlaksanaan seluruh pembelajaran pada siklus pertama adalah $77,94 \%$ sehingga keterlaksanaan pembelajaran dapat dikatakan belum berjalan optimal. Kemudian dilakukan pengukuran terhadap kepercayaan diri siswa dengan angket. Setelah diperolehnya hasil angket, kegiatan refleksi dilakukan melalui tahap analisis dan evaluasi setelah dilakukan tindakan pada siklus I. Refleksi dilakukan berdasarkan hasil tes dan lembar observasi. Hasil dari refleksi adalah sebagai berikut: (a) Dalam proses pembelajaran pertemuan pertama siklus 1 ini, siswa masih banyak yang kurang merespon pembelajaran dengan menggunakan model pembelajaran kooperatif TPS. (b) Ketika diminta untuk berkelompok dan berdiskusi sesuai dengan kelompok yang telah ditentukan, siswa tidak langsung tanggap untuk membentuk kelompok sampai guru harus mengingatkan beberapa kali. (c) Pada tahap think, masih ada siswa yang tidak serius mengerjakan LKS dan langsung berdiskusi dengen temannya baik dengan pasangannya pada tahap pair ataupun bukan. (d) Pada tahap pair, masih banyak pasangan siswa yang tidak saling berdiskusi. Siswa hanya menyalin pekerjaan temannya. Sebagian besar pasangan bekerja sama dengan pasangan lain baik kelompoknya ataupun bukan. (e) Pada tahap square, masih ada siswa yang bergurau. Masih tampak pula siswa yang tidak mau berdiskusi. (f) Siswa belum percaya diri dalam mengajukan pertanyaan atau memberikan pendapat. (g) Siswa masih menolak ketika diminta menyampaikan kesimpulan di hadapan kelas. (h) Keterlaksanaan proses pembelajaran belum mencapai target yang diinginkan dikarenakan kurang tegasnya peneliti pada rencana alokasi waktu tiap tahap pembelajaran.

Dari beberapa kekurangan di siklus 1 tersebut didapatkan rekomendasi sebagai rencana perbaikan untuk pembelajaran pada siklus 2 yaitu: (a) Peneliti harus memotivasi siswa dan melakukan bimbingan secara intensif baik pada saat diskusi kelompok maupun diskusi kelas. (b) Peneliti perlu memberikan motivasi yang lebih bagi siswa untuk mempresentasikan hasil diskusi kelompoknya dan menanggapi hasil diskusi kelompok lain. (c) Peneliti harus mendorong siswa untuk lebih aktif dalam pembelajaran. (d) Peneliti harus memberi pemahaman yang lebih mengenai kegunaan tahap think. Arahan yang diberikan berupa informasi pentingnya kegiatan pada tahap think sebagai bekal siswa untuk memahami materi yang akan dipelajari dan sebagai modal untuk berdiskusi pada tahap pair dan square. (e) Pada tahap pair, peneliti akan memberikan arahan pada siswa untuk berdiskusi dengan pasangannya. (f) Pada tahap square, peneliti memberikan arahan dan motivasi pada siswa tentang pentingnya diskusi kelompok dalam memahami materi. (g) Peneliti harus lebih tegas dalam alokasi waktu tiap tahapan sesuai dengan yang telah direncanakan. (h) Peneliti harus mendorong siswa untuk lebih percaya diri lagi dalam kegiatan pembelajaran matematika.

Pada siklus 2, proses pelaksanaan disesuaikan dengan hasil refleksi siklus 1. Pelaksanaan tindakan pada siklus 2 ini merupakan kelanjutan pada siklus I. Pada siklus 1 belum mencapai target yang diharapkan, sehingga perlu dilanjutkan pada siklus II. Untuk mencapai keberhasilan pada siklus II, peneliti dan observer membuat proses pembelajaran seperti pada siklus I. Hasil perencanaan yang telah dibuat kemudian didiskusikan bersama guru matematika selaku observer dan meminta saran mengenai poin-poin dalam rancangan pembelajaran. Pelaksanaan siklus 2 dilakukan dalam tiga pertemuan. Pengamatan yang dilakukan observer berupa pengamatan terhadap proses keterlaksanaan pembelajaran, dengan lembar observasi yang berisi pernyataan tentang proses pembelajaran di kelas. Berdasarkan data pada lembar observasi diperoleh bahwa keterlaksanaan pembelajaran pada siklus 2 mencapai 89,21\%. Kegiatan refleksi dilakukan melalui tahap analisis dan evaluasi setelah dilakukan tindakan pada siklus 2. Refleksi dilakukan 
berdasarkan hasil tes dan lembar observasi. Peneliti melakukan kegiatan refleksi bersama observer yaitu guru mata pelajaran matematika. Berdasarkan analisis terlihat bahwa hasil penelitian pada siklus 2 sudah target yang diinginkan. Oleh karena itu penelitian tindakan kelas akan dihentikan

\section{Pembahasan}

Berdasarkan hasil observasi keterlaksanaan pembelajaran ditemukan bahwa terjadi peningkatan. Hal ini dapat dilihat pada tabel berikut.

Tabel 6. Hasil Observasi Keterlaksanaan Proses Pembelajaran

\begin{tabular}{cccccc}
\hline Siklus & Pertemuan & $\begin{array}{c}\text { Kegiatan } \\
\text { Guru }\end{array}$ & $\begin{array}{c}\text { Kegiatan } \\
\text { Siswa }\end{array}$ & Rata-rata & $\begin{array}{c}\text { Rata-rata Akhir } \\
\text { Siklus }\end{array}$ \\
\hline 1 & 1 & $64,71 \%$ & $85,71 \%$ & $75,21 \%$ & $77,94 \%$ \\
& 2 & $70,59 \%$ & $78,57 \%$ & $74,58 \%$ & \\
2 & 3 & $82,35 \%$ & $85,71 \%$ & $84,03 \%$ & \\
& 4 & $88,23 \%$ & $85,71 \%$ & $86,97 \%$ & $89,21 \%$ \\
& 5 & $87,09 \%$ & $87,09 \%$ & $87,09 \%$ & \\
\hline
\end{tabular}

Dari tabel tersebut dapat terlihat bahwa proses pembelajaran tiap pertemuan semakin meningkat. Namun terjadi penurunan keterlaksanaan kegiataan siswa pada pertemuan kedua dalam siklus 1 . Hal ini disebabkan oleh masih kurangnya pemahaman siswa mengenai model pembelajaran kooperatif Think Pair Square. Persentase keterlaksanaan seluruh pembelajaran pada siklus pertama adalah $89,21 \%$ artinya keterlaksanaan pembelajaran secara keseluruhan pada siklus 2 dikatakan belum berjalan optimal. Namun jika dilihat pada keterlaksanaan pembelajaran pertemuan keenam maka pembelajaran sudah dikatakan optimal dan mencapai kriteria keberhasilan tindakan.

Untuk hasil skor angket kondisi awal, akhir siklus 1, dan akhir siklus 2dapat dilihat pada tabel berikut.

Tabel 7. Skor Angket

\begin{tabular}{cccccc}
\hline Interval & Kriteria & Kondisi Awal & Target & Akhir Siklus 1 & Akhir Siklus 2 \\
\hline $126<\mathrm{X}$ & Sangat Tinggi & $0 \%$ & $16,67 \%$ & $3,33 \%$ & $23,33 \%$ \\
$102<\mathrm{X} \leq 126$ & Tinggi & $6,67 \%$ & $66.67 \%$ & $63,33 \%$ & $63,33 \%$ \\
$78<\mathrm{X} \leq 102$ & Sedang & $80 \%$ & $16,67 \%$ & $33,33 \%$ & $13,33 \%$ \\
$54<\mathrm{X} \leq 78$ & Rendah & $13,33 \%$ & $0 \%$ & $0 \%$ & $0 \%$ \\
$\mathrm{X}<54$ & Sangat Rendah & $0 \%$ & $0 \%$ & $0 \%$ & $0 \%$ \\
\hline Rata-rata & Sedang & 87.23 & Tinggi & 103,53 & 114,36 \\
\hline
\end{tabular}

Dari tabel tersebut dapat terlihat bahwa siswa yang memperoleh kategori sangat tinggi meningkat dari $0 \%$ menjadi $23,33 \%$ dan untuk kategori tinggi meningkat dari $6,67 \%$ menjadi $63,33 \%$. Hal ini memperlihatkan bahwa ada siswa yang kepercayaan dirinya meningkat. Untuk kategori sesang menurun dari $80 \%$ menjadi $13,33 \%$ dan untuk kategori sangat rendahjuga menurun dari 13,33\% menjadi $0 \%$. Hal ini memperlihatkan bahwa ada pengurangan jumlah siswa yang tingkat kepercayaan dirinya sedang dan rendah. Sejalan dengan peningkatan kategori kepercayaan diri siswa masing-masing individu, rata-rata skor kepercayaan diri kelas juga meningkat dari 87,23 dengan kategori sedang menjadi 114,36 dengan kategori tinggi. Berdasarkan kondisi akhir siklus 2, terlihat bahwa target peningkatan kepercayaan diri siswa tercapai. 


\section{E. Simpulan}

Setelah dua siklus ternyata kepercayaan diri siswa meningkatyakni dari rata-rata skor angket 87,23 dengan kriteria sedang menjadi 114,36 dengan kriteria tinggi dengan menerapkan model pembelajaran kooperatif TPS. Keterlaksanaan proses pembelajaran juga membaik dari keterlaksanaan yang kurang dari 90\% menjadi lebih dari $90 \%$.

\section{DAFTAR PUSTAKA}

Adywibowo, L.P. (2010). Memperkuat kepercayaan diri anak melalui percakapan referensial. Jurnal Pendidikan Penabur No. 15/Tahun ke-9/Desember 2010. Jakarta: Prenada Media Group.

Aisah, S., Ashari, H., \& Akhdinirwanto, R.W. (2013). Penggunaan model pembelajaran cooperative learning tipe think pair square berbantuan kartu soal untuk meningkatkan aktivitas belajar siswa kelas VII b SMP Negeri 5 Purworejo. Abstrak Hasil Penelitian Universitas Muhammadiyah Purworejo. Purworejo

Arends, R.L., \& Kilcher, A. (2010). Teaching for student learning becoming an accomplished teacher. New York: Routledge.

Brockbank, A., \& McGill, I. (2007).Facilitating reflective learning in higher education. London: Mc-Graw Hill.

Depdiknas. 2003. Permendiknas No 20/2003: Sistem pendidikan nasional. Jakarta: BSNP.

Goel, M. \& Aggarwal, P. (2012). A comparative study of self confident of single child and child with sibling. International Journal Research in Social Sciences, 2, 89-98.

Hamalik, Oemar. (2007). Proses belajar mengajar. Jakarta: Bumi Aksara.

Hannula, M.S., Maijala, H., \& Pehkonen, E. (2004). Development of understanding selfconfidence in mathematics grades 5-8. Group for the Psychology of Mathematics Education. 3, 17-24.

Haylock, D. \& Tangatha, F. (2007). Key concept in teaching primary mathematics. London, UK: Sage Publication.

Hebaish, SM. (2012). The correlation between generalself-confidence and academic achievement in the oralpresentation course. Theory and Practice in Language Studies. 2(1), 60- 65.

Hendriana, Heris. (2012). Pembelajaran matematika humanis dengan metaphorical thinking untuk meningkatkan kepercayaan diri siswa. Jurnal Ilmiah. 1(1).

Ibrahim, M., Rachmadiarti, F., Nur, M., \& Ismono. (2001). Pembelajaran kooperatif. Surabaya: UNESA - University Press.

JIST Live. (2006). Young person's caracter education handbook. Indianapolis, IN: JIST Publishing, Inc.

Kemendikbud. (2013). Permendikbud no 65/2013: Standar proses pendidikan dasar dan menengah. BSNP. Jakarta

Kemp, J.E., Morisson, G., \& Ross, S.M. (1985). Designing effective instruction. New York: Macmillan College Publishing Company.

Lie, Anita. (2008). Cooperative learning: Mempraktikkan cooperative learning di ruang-ruang kelas. Jakarta: Grasindo.

NCTM. (2000). Principles and standards for school mathematics. Reston: National Concil of Teacher of Mathematics.

Nitko, A.J. \& Brookhart, S.M. (2011). Educational asessment of student. Boston: Pearson Education.

Orlich, et al. (2007). Teaching strategies a guide to effective instruction. Boston: Houghton Mifflin Company.

Sanjaya, Wina. (2010). Perencanaan dan desain sistem pembelajaran. Jakarta: Kencana. 
Scunk, D.H. (2012). Learning theories: An educational perspective. Boston, MA: Pearson Education.

Slavin, Robert E. (2005). Cooperative learning: Theory, research, and practice. Boston: Ally and Bacon.

Srivastava, S.K. (2013). To study the effect of academic achievement on the level of self confident. J. Psychosoc. Res., 8(1), 41-51.

Suherman, E., dkk. (2003). Ragam metode mengajar eksata pada murid. Yogyakarta: DIVA Press.

Susanti, Martina. (2010). Meningkatkan motivasi, aktivitas, dan hasil belajar siswa kelas X animasi 2 SMK Negeri 11 Semarang pada materi bilangan riil melalui pembelajaran kooperatif kombinasi STAD-TGT berbantuan media CD pembelajaran. Abstrak Skripsi. Universitas Negeri Semarang

Syaifullah, Ach. (2010). Tips bisa percaya diri. Jakarta: Gara Ilmu.

Trianto. (2011). Mendesain model pembelajaran inovatif-progresif: Konsep, landasan, dan implementasinya pada kurikulum tingkat satuan pendidikan (KTSP). Jakarta: Prestasi Pustaka.

Uno, H.B. (2008). Teori motivasi dan pengukurannya. Jakarta: Bumi Aksara.

Van De Walle, J.A. (2007). Sekolah dasar dan menengah matematika pengembagan dan pengajaran. Jakarta: Erlangga.

Yoder, J. \& Proctor, W. (1988). The self-confident child. New York, NY:Fact on File Publication.

Young, Michael. (2015). What is learning and why does it matter?. European Journal of Education, 50(4), 524. 